\title{
Biliary Excretion of $\left[{ }^{14} \mathrm{C}\right]$ Succinylsulphathiazole in the Rat and Rabbit
}

\author{
By M. M. ABOU-EL-MAKAREM, P. MILLBURN AND R. L. SMITH \\ Department of Biochemistry, St Mary's Hospital Medical School, London, W. 2
}

(Received 5 July 1967)

\begin{abstract}
1. After intravenous injection about $30 \%$ of the dose $(20 \mathrm{mg} . / \mathrm{kg}$.$) of succinyl-$ sulphathiazole is excreted unchanged in the bile in $3 \mathrm{hr}$. by the rat, whereas only about $1 \%$ is excreted by the rabbit. When the renal pedicles are ligated the biliary excretion of succinylsulphathiazole in the rat increases to about $80 \%$ of the dose, but in the rabbit under these conditions the biliary excretion is only $2 \%$ of the dose. 2 . In the rat, the sulphonamide readily enters the liver and biliary excretion occurs against a concentration gradient from liver to bile; further, the excretory process can be saturated, and can be depressed by the simultaneous administration of phenolphthalein glucuronide or bile salts. 3. In the rabbit, these conditions have not been found; succinylsulphathiazole does not readily enter the liver from the plasma, there is no transfer of the drug from the liver cells to the bile against a concentration gradient, and no saturation or depression of the biliary excretion of succinylsulphathiazole is found. 4. It is suggested that two factors responsible, at least partly, for the low biliary excretion of succinylsulphathiazole in the rabbit are the poor entry of the sulphonamide into the liver in this species and a deficiency of the concentrative mechanism for its excretion in the bile.
\end{abstract}

Previous studies have shown that there are marked species differences in the biliary excretion of some foreign compounds (Abou-El-Makarem, Millburn, Smith \& Williams, 1967b). Though there was little species variation in the biliary excretion of several low-molecular-weight benzene derivatives whose biliary excretion in all cases was small, marked variations were found for four compounds of higher molecular weight, namely succinylsulphathiazole, stilboestrol glucuronide, sulphadimethoxine $N^{1}$-glucuronide and phenolphthalein glucuronide. For these four compounds, the rat, dog and hen were found to be good excretors and the rabbit, guinea pig and rhesus monkey poor excretors, the cat and sheep being intermediate.

The biliary excretion of $\left[{ }^{14} \mathrm{C}\right]$ succinylsulphathiazole in the rat (an example of a good biliary excretor) and in the rabbit (a poor excretor) has now been investigated in detail, in an attempt to elucidate the factors responsible for the difference in biliary excretion of the drug in these species. A preliminary report of this work has appeared (Abou-El-Makarem, Millburn, Smith \& Williams, $1967 a)$.

\section{MATERIALS AND METHODS}

Animals. Female Wistar albino rats $(200 \pm 20 \mathrm{~g}$. wt. $)$ and New Zealand White does $(3 \pm 0 \cdot 25 \mathrm{~kg}$. wt.) were cannulated as described by Abou-El-Makarem, Millburn, Smith \& Williams $(1967 b, c)$. In some experiments both renal pedicles (renal artery, vein and ureter) of cannulated animals were ligated, thus stopping urine formation.

Chemicals. Succinylsulphathiazole, m.p. $186-188^{\circ}$ (from May and Baker Ltd., Dagenham, Essex) and sodium phenolphthalein glucuronide, sodium glycocholate and sodium taurocholate (all from Koch-Light Laboratories Ltd., Colnbrook, Bucks.) were purchased.

Synthesis of $\left[{ }^{14} \mathrm{C}\right]$ succinylsulphathiazole. $\quad\left[1,4-{ }^{14} \mathrm{C}_{2}\right]-$ Succinic acid ( $200 \mathrm{mg}$.; $500 \mu \mathrm{c})$ was refluxed for $2 \mathrm{hr}$. with acetyl chloride $\left(0.5 \mathrm{ml}\right.$.). The $\left[{ }^{14} \mathrm{C}\right]$ succinic anhydride that separated (130 mg.) on cooling in an ice bath was filtered and washed three times with ether. It was added to a hot solution of sulphathiazole ( $300 \mathrm{mg}$.) in ethanol $(5 \mathrm{ml}$.) and refluxed for $45 \mathrm{~min}$. On standing at $0^{\circ}$ overnight $\left[{ }^{14} \mathrm{C}\right]$ succinylsulphathiazole separated as a white precipitate, which was filtered and recrystallized from aq. $80 \%(\mathrm{v} / \mathrm{v})$ ethanol to give white needles $\left(220 \mathrm{mg}\right.$.; m.p. $186^{\circ}$; specific activity $2 \mu \mathrm{c} / \mathrm{mg}$.). When chromatographed on strips of Whatman no. 1 paper, with the solvents given below, and scanned by a Packard Radiochromatogram Scanner (model 7200 ), it gave only one radioactive peak, corresponding to the authentic succinylsulphathiazole.

Colorimetric determinations. In some experiments succinylsulphathiazole was determined colorimetrically as described by Millburn, Smith \& Williams (1967a). For plasma and liver a preliminary deproteinization was necessary. Plasma samples (1-2 ml.) obtained by centrifuging blood at $2000 \mathrm{rev} . / \mathrm{min}$. for $10 \mathrm{~min}$. in the MSE Minor centrifuge and $5 \mathrm{ml}$. portions of liver homogenates $(20 \%$ in $0.9 \% \mathrm{NaCl}$ ) were treated with $5 \mathrm{vol}$. of trichloroacetic acid $(10 \%, w / v)$. Proteins were removed by centrifuging at $2000 \mathrm{rev}$. $/ \mathrm{min}$. for $10 \mathrm{~min}$. in the MSE Minor centrifuge and portions $(1-5 \mathrm{ml}$.) of the supernatant were assayed for 
succinylsulphathiazole. The recovery of succinylsulphathiazole added to control bile, plasma and liver homogenates was $97 \%$ (range 90-102\%). Phenolphthalein glucuronide in bile was assayed as described by Millburn, Smith \& Williams (1967b).

Measurement of ${ }^{14} \mathrm{C}$ radioactivity. Plasma samples $(0.5 \mathrm{ml}$.), obtained as above, were added to $20 \mathrm{ml}$. of a scintillation fluid consisting of dioxan-ethylene glycolmethanol (44:1:5, by vol.) containing naphthalene $(6 \%)$, 2,5-diphenyloxazole $(0 \cdot 4 \%)$, 1,4-bis-(5-phenyloxazol-2-yl) benzene $(0.02 \%)$ and thixotropic gel powder (Cab-O-Sil) $(5 \%)$, and the ${ }^{14} \mathrm{C}$ radioactivity was measured in a Packard Tri-Carb Scintillation Spectrometer (model 3214). Liver samples (2g.) were homogenized in $20 \mathrm{ml}$. of equal parts of dioxan and methanol. Portions $(0.5-1 \mathrm{ml}$.) of the homogenate were added to $20 \mathrm{ml}$. of the scintillation fluid. Bile samples (15-50 mg.) were added to a scintillation fluid of the above composition but without the thixotropic gel powder. Counting efficiencies (determined by the twin-channel ratio method) were as follows: plasma, $71 \%$; bile, $65 \%$; liver, $56-77 \%$.

Chromatography. Samples were chromatographed on Whatman no. 1 paper by the descending technique with the following solvent systems: $A$, butan-1-ol-acetic acid-water (4:1:2, by vol.); $B$, butan-1-ol-aq. $\mathrm{NH}_{3}$ (sp.gr. 0.88)-water (10:1:1, by vol); $C$, propan-1-ol-aq. $\mathrm{NH}_{3}$ (sp.gr. 0.88 ) $(7: 3, v / v)$. The $R_{F}$ values of succinylsulphathiazole in these solvents were: $A, 0.79 ; B, 0.05 ; C, 0.41$. Samples $(0.05-0.1 \mathrm{ml}$.) of bile were chromatographed directly, but plasma and liver homogenate samples were first deproteinized as described above. Succinylsulphathiazole was detected on paper chromatograms with u.v. light, when it appeared as a dark quenching spot, and by spraying with a $0.25 \%$ solution of $p$-dimethylaminocinnamaldehyde dissolved in equal parts of ethanol and $2 \mathrm{~N}-\mathrm{HCl}$, when after standing for 6-24 hr. the sulphonamide appeared as a red spot on a white background. Paper-strip chromatograms of samples obtained from animals treated with $\left[{ }^{14} \mathrm{C}\right]-$ succinylsulphathiazole were scanned for ${ }^{14} \mathrm{C}$ with the radiochromatogram scanner.

Distribution studies. For studying the distribution of succinylsulphathiazole, the labelled compound $(50 \mathrm{mg} . / \mathrm{kg}$. intraperitoneally or intravenously) was injected into biliary-cannulated rats and rabbits with or without ligated pedicles. Groups (three to five animals) were killed at 15, $30,60,120$ and $180 \mathrm{~min}$. after the injection by bleeding from the carotid arteries. Blood and liver samples were taken and a bile sample was collected into a tared vessel for 1-2 min. before the death of the animal.

\section{RESULTS AND DISCUSSION}

Biliary excretion of $\left[{ }^{14} \mathrm{C}\right]$ succinylsulphathiazole in the rat and rabbit. The quantitative aspects of the biliary excretion of $\left[{ }^{14} \mathrm{C}\right]$ succinylsulphathiazole by the rat and rabbit are shown in Table 1 . The rat excretes about 50 times as much succinylsulphathiazole in the bile in the first $3 \mathrm{hr}$. after intraperitoneal administration as does the rabbit, and about 40 times as much if the renal pedicles are ligated to block urinary excretion. This difference in biliary excretion of the drug is not due to differences in absorption from the peritoneal cavity after
Table 1. Biliary excretion of $\left[{ }^{14} \mathrm{C}\right]$ succinylsulphathiazole in the rat and rabbit

$\left[{ }^{14} \mathrm{C}\right]$ Succinylsulphathiazole (20 mg./kg.; $10 \mu \mathrm{c} / \mathrm{kg}$.) in water as the sodium salt was injected intraperitoneally (i.p.) or intravenously (i.v.) into biliary-cannulated female rats or rabbits, and bile was collected for $3 \mathrm{hr}$. and analysed for succinylsulphathiazole. The results are means for three animals with ranges in parentheses.

$\begin{array}{cccc}\text { Animal } & \begin{array}{c}\text { Route of } \\ \text { injection }\end{array} & \begin{array}{c}\text { Renal pedicles } \\ \text { not ligated }\end{array} & \begin{array}{c}\text { Renal pedicles } \\ \text { ligated }\end{array} \\ \text { Rat } & \text { i.p. } & 19(12-26) & 76(64-83) \\ & \text { i.v. } & 34(22-46) & 82(70-91) \\ \text { Rabbit } & \text { i.p. } & 0.4(0.2-0 \cdot 7) & 1.9(1 \cdot 1-3 \cdot 0) \\ & \text { i.v. } & 1.3(0.6-2 \cdot 4) & 2.5(2 \cdot 2-2 \cdot 9)\end{array}$

intraperitoneal injection, since the biliary excretion was still very low in the rabbit after intravenous injection but conversely it was high in the rat. Paper chromatography of bile samples from treated rats and rabbits in solvents $A, B$ and $C$ revealed only one spot, with $R_{F}$ values that corresponded to the unchanged sulphonamide. Similar results were obtained with unlabelled succinylsulphathiazole and colorimetric estimation. Also, the low biliary excretion of succinylsulphathiazole in the rabbit is not due to its rapid excretion in the urine, since its biliary excretion only increased slightly $(2 \%$ of dose) after ligating the renal pedicles.

Distribution of $\left[{ }^{14} \mathrm{C}\right]$ succinylsulphathiazole in the rat and rabbit. The distribution of succinylsulphathiazole between the plasma, liver and bile of the rat and rabbit at $0-180 \mathrm{~min}$. after an injection of the sulphonamide is shown in Fig. 1. In the rat after an intraperitoneal dose of $50 \mathrm{mg} . / \mathrm{kg}$. the plasma concentrations are consistently much lower than those found in the liver and bile, showing that the drug is passing to the liver and into the bile against a marked concentration gradient. Thus at $30 \mathrm{~min}$. after injection the bile concentration of the drug is about 3.5 times that of the liver and 15 times that of the plasma. The reverse situation obtains for the rabbit, for the liver and bile concentrations of the sulphonamide are less than those of the plasma, even though the latter are higher than those found in the rat. In the rabbit the drug does not appear to equilibrate or concentrate in the hepatic cells as in the rat, and apparently no transfer of the drug from the liver cells to the bile against a concentration gradient occurs. The plasma proteinbinding of succinylsulphathiazole $(200 \mu \mathrm{g} . / \mathrm{ml}$. of plasma) was $17 \%$ for the rat and $19 \%$ for the rabbit (measured by the Toribara ultrafiltration technique) suggesting that extensive plasma protein-binding is not responsible for preventing the entry of 


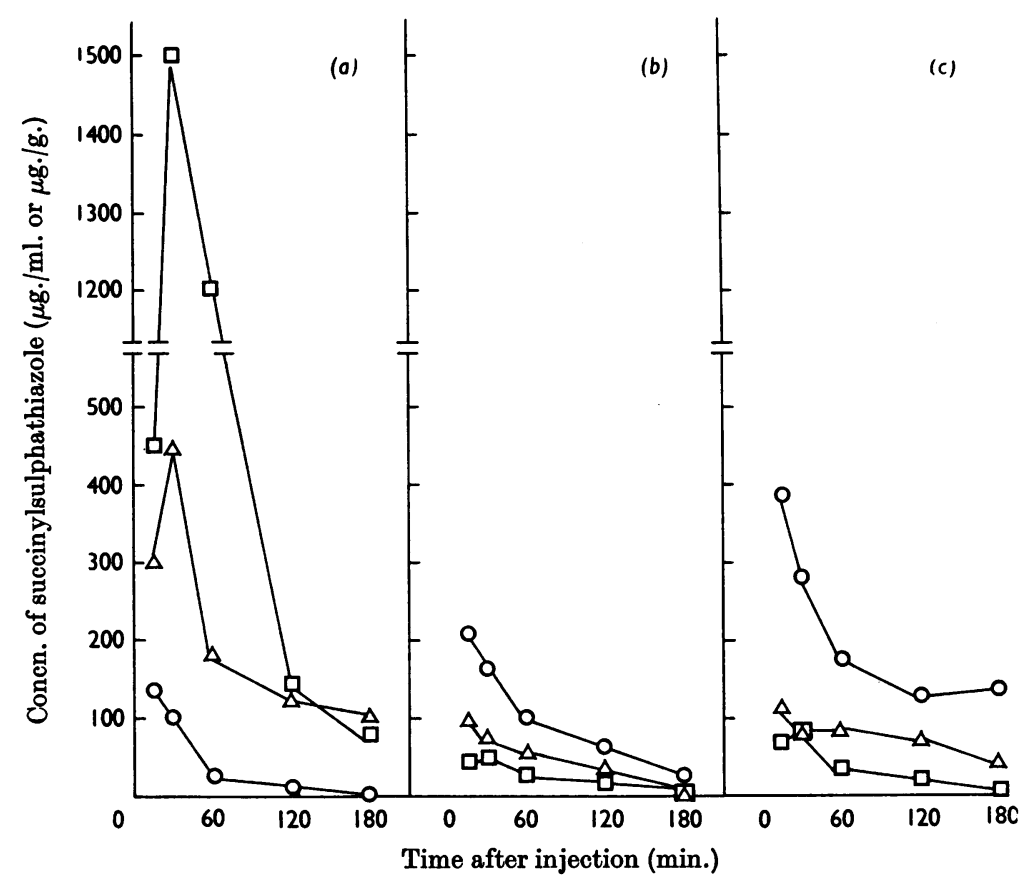

Fig. 1. Distribution of succinylsulphathiazole between plasma, liver and bile of the rat and rabbit. Succinylsulphathiazole $(50 \mathrm{mg} . / \mathrm{kg}$.) was administered to rats (intraperitoneally) and to rabbits (intravenously) as an aqueous solution of its sodium salt. The concentration of succinylsulphathiazole is expressed as $\mu \mathrm{g} . / \mathrm{ml}$. for plasma and bile and $\mu \mathrm{g} . / \mathrm{g}$. for liver. Results are the means of three experiments. $(a)$ Rat; $(b)$ rabbit (renal pedicles not ligated); (c) rabbit (renal pedicles ligated). $O$, Plasma; $\Delta$, liver; $\square$, bile.

succinylsulphathiazole into the hepatic cells of the rabbit.

Ligation of the renal pedicles of rabbits treated with succinylsulphathiazole $(50 \mathrm{mg} . / \mathrm{kg}$. intravenously) doubled the plasma concentrations of the sulphonamide over those found in non-ligated animals, but the liver and bile concentrations were still less than those of the plasma, suggesting that the drug enters the liver only with difficulty.

Effect of dose level on the biliary excretion of $\left[{ }^{14} \mathrm{C}\right]$ succinylsulphathiazole. $\quad\left[{ }^{14} \mathrm{C}\right]$ Succinylsulphathiazole was administered at various dose levels to rats and rabbits with ligated renal pedicles and the amount of the drug excreted in the bile estimated. At doses of $27-268 \mu \mathrm{moles} / \mathrm{kg}$. about $80 \%$ of the dose is excreted in the bile in $3 \mathrm{hr}$. by the rat. Fig. 2 shows that the actual amount of succinylsulphathiazole excreted in the bile increases to a maximum of about $230 \mu \mathrm{moles} / \mathrm{kg}$. body wt. $/ 3 \mathrm{hr}$. at a dose of $268 \mu \mathrm{moles} / \mathrm{kg}$. and then remains at this value even though the dose is raised to $1340 \mu \mathrm{moles} / \mathrm{kg}$. Thus at dose levels between 268 and $1340 \mu$ moles $/ \mathrm{kg}$. the percentage of the dose excreted in the bile falls from $86 \%$ to $17 \%$. The results suggest that saturation of one or more points of the mechanism involved in

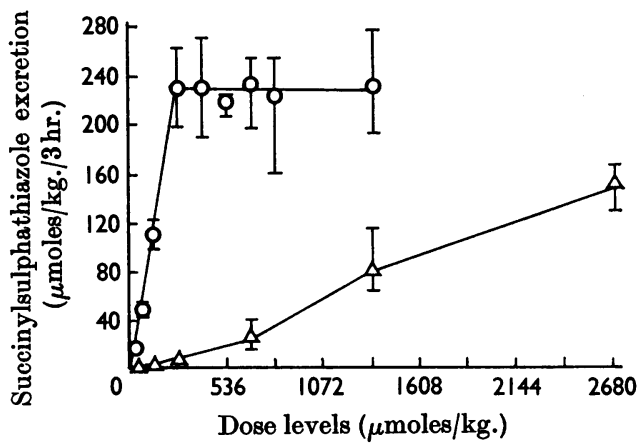

Fig. 2. Biliary excretion of various doses of $\left[{ }^{14} \mathrm{C}\right]$ succinylsulphathiazole by the rat and rabbit with ligated renal pedicles. Succinylsulphathiazole was administered to rats (intraperitoneally) and to rabbits (intravenously) as an aqueous solution of its sodium salt. Bile was collected for $3 \mathrm{hr}$. Results are the means of three experiments; ranges are represented by vertical bars. O, Rat; $\Delta$, rabbit.

the biliary excretion of succinylsulphathiazole has occurred. By contrast, in the rabbit the amount of succinylsulphathiazole excreted in the bile gradually 


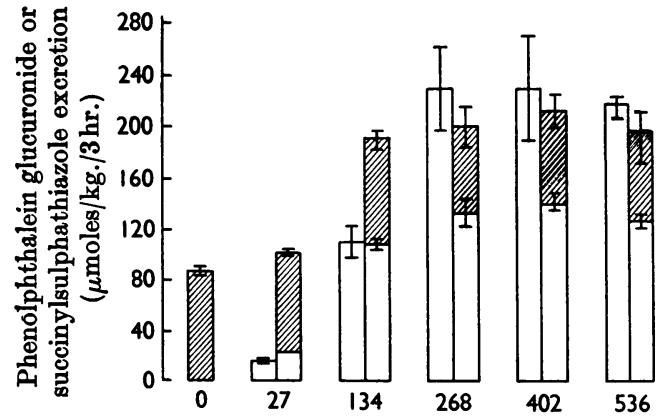

Dose level of succinylsulphathiazole ( $\mu$ moles $/ \mathrm{kg}$.)

Fig. 3. Effect of phenolphthalein glucuronide on the biliary excretion of succinylsulphathiazole in rats with ligated renal pedicles. An aqueous solution of sodium phenolphthalein glucuronide $(97 \mu \mathrm{moles} / \mathrm{kg}$.) was injected intraperitoneally $1 \mathrm{~min}$. before the dose of succinylsulphathiazole and bile was collected for $3 \mathrm{hr}$. Results are the means of three experiments; ranges are represented by vertical bars. The Figure shows rates of excretion of phenolphthalein glucuronide (E) and succinylsulphathiazole ( $\square$ ). The first block at each dose level represents the extent of biliary excretion of succinylsulphathiazole when administered alone and the second block indicates the excretion of both succinylsulphathiazole and phenolphthalein glucuronide when administered together.

increases from 1.3 to $155 \mu$ moles $/ \mathrm{kg}$. body wt. $/ 3 \mathrm{hr}$. (2-6\% of the dose) with increase of the dose from 54 to $2680 \mu$ moles $/ \mathrm{kg}$., but no maximum was reached (see Fig. 2). Thus the excretory process can be saturated in the rat but not in the rabbit.

Effect of phenolphthalein glucuronide and bile salts on the biliary excretion of succinylsulphathiazole. Phenolphthalein glucuronide is excreted unchanged in rat bile to the extent of about $50 \%$ of the dose in $3 \mathrm{hr}$. (Abou-El-Makarem et al. 1967b). When phenolphthalein glucuronide is administered at dose levels of 19-725 $\mu \mathrm{moles} / \mathrm{kg}$. to rats with ligated renal pedicles, the amount excreted in the bile increases to a maximum of about $230 \mu \mathrm{moles} / \mathrm{kg}$. body wt. $/ 3 \mathrm{hr}$. at a dose level of $290 \mu \mathrm{moles} / \mathrm{kg}$. and remains constant on increasing the dose to $725 \mu \mathrm{moles} / \mathrm{kg}$. (M. M. Abou-El-Makarem, P. Millburn, R. L. Smith \& R. T. Williams, unpublished work). Therefore the biliary excretion of phenolphthalein glucuronide in the rat, like that of succinylsulphathiazole, can be saturated, both compounds showing similar maxima for the amount excreted in bile (about $230 \mu \mathrm{moles} / \mathrm{kg}$. body wt./3 hr.).

The influence of an injected dose (97 $\mu$ moles/kg.) of phenolphthalein glucuronide on the biliary excretion of various doses $(27-536 \mu \mathrm{moles} / \mathrm{kg}$.) of succinylsulphathiazole in the rat is shown in Fig. 3. At dose levels of 27 and $134 \mu \mathrm{moles} / \mathrm{kg}$. the biliary
Table 2. Effect of sodium taurocholate on the biliary excretion of succinylsulphathiazole in rats with ligated resal pedicles

The taurocholate was injected intraperiteonally $15 \mathrm{~min}$. before the succinylsulphathiazole $(268 \mu$ moles $/ \mathrm{kg}$. intraperitoneally) as an aqueous solution of the sodium salt. Results are the means of three or more animals with ranges in parentheses.

$\begin{array}{ccc}\begin{array}{c}\text { Dose of } \\ \text { sodium } \\ \text { taurocholate } \\ (\mu \mathrm{moles} / \mathrm{kg} .)\end{array} & \begin{array}{c}\text { \% of dose of } \\ \text { succinylsulpha- } \\ \text { thiazole in bile } \\ \text { in } 3 \mathrm{hr} .\end{array} & \begin{array}{c}\text { Succinylsulphathiazole } \\ \text { excretion } \\ (\mu \text { moles } / \mathrm{kg} . / 3 \mathrm{hr} .)\end{array} \\ 0 & 86(74-98) & 231(198-263) \\ 17 & 65(63-67) & 174(169-180) \\ 44 & 50(43-55) & 134(115-148) \\ 87 & 44(29-60) & 118(78-161) \\ 174 & 42(30-51) & 113(80-137)\end{array}$

excretion of succinylsulphathiazole is unaffected by the simultaneous administration of phenolphthalein glucuronide. However, at higher dose levels (268-536 $\mu$ moles $/ \mathrm{kg}$.) the biliary excretion of the succinylsulphathiazole is markedly depressed. There also occurs a small decrease in the biliary excretion of the phenolphthalein glucuronide. These results suggest that phenolphthalein glucuronide and succinylsulphathiazole compete with each other for excretion in the bile and that they there. fore must share at least part of a common excretory process. A second point shown by these studies is that the biliary excretion mechanism has a limited capacity and that it can be saturated. Thus the maximum rate of biliary excretion of both succinylsulphathiazole and phenolphthalein glucuronide is about $230 \mu \mathrm{moles} / \mathrm{kg}$. body wt. $/ 3 \mathrm{hr}$. and this remains fairly constant even with increasing dose levels of the compound. In the presence of phenolphthalein glucuronide, although the biliary excretion of succinylsulphathiazole is depressed, the total number of molecules, expressed as $\mu \mathrm{moles} / \mathrm{kg}$. body wt./3 hr., of the two compounds excreted in the bile is the same as that seen at saturation dose levels of either the sulphonamide or phenolphthalein glucuronide alone.

Table 2 shows the effect of various doses (17$174 \mu \mathrm{moles} / \mathrm{kg}$.) of sodium taurocholate on the biliary excretion of succinylsulphathiazole (268 $\mu$ moles/kg.). The results suggest that the sulphonamide and the bile salt compete with each other for elimination in the bile in the rat, since the taurocholate depresses the excretion of succinylsulphathiazole. In these experiments the excretion of the bile salt itself was not determined. By contrast, the biliary excretion of succinylsulphathiazole in the rabbit was not depressed by pretreatment of the animal with either sodium glycocholate or phenol. 


\section{Table 3. Effect of sodium glycocholate and phenolphthalein glucuronide on the biliary excretion of succinylsulphathiazole in rabbits}

All compounds were administered as aqueous solutions of their sodium salts. Where indicated, sodium glycocholate and phenolphthalein glucuronide were administered 15 and $1 \mathrm{~min}$. respectively before the dose of succinylsulphathiazole. Results are the means for three or more animals with ranges in parentheses. i.p. Intraperitoneal; i.v., intravenous.

\author{
Dose of \\ succinylsulphathiazole \\ ( $\mu$ moles/kg.)
}

134

268

268
$\%$ of dose of succinylsulphathiazole in $3 \mathrm{hr}$.

$\begin{array}{cc}\begin{array}{c}\text { Renal pedicles } \\ \text { not ligated }\end{array} & \begin{array}{c}\text { Renal pedicles } \\ \text { ligated }\end{array} \\ 0.6(0.2-1 \cdot 0) & 2.0(1 \cdot 6-2 \cdot 5) \\ 0.9(0.5-1 \cdot 2) & 5 \cdot 1(2 \cdot 4-7 \cdot 2) \\ 1.2(0.6-1 \cdot 7) & 2.6(1.9-3 \cdot 2) \\ 1.9(1.8-2 \cdot 1) & 3.0(1.9-4 \cdot 1) \\ - & 2.6(1.9-3.2) \\ & 2.5(1.8-2.9)\end{array}$

phthalein glucuronide (Table 3). In fact, administration of the former elicited a small increase in the amount of the sulphonamide excreted in the bile. Thus, under the conditions of the experiment, it appears that in the rabbit succinylsulphathiazole does not compete with bile salt or phenolphthalein glucuronide for elimination in the bile.

These findings clearly show that the pattern of biliary excretion of succinylsulphathiazole in the rat differs from that in the rabbit in several respects. The excretion is much higher in the rat than in the rabbit. This difference is due to factors other than variations in absorption and metabolism since it occurs when the compound is given intravenously and, further, the drug is not metabolized and is excreted unchanged in both species.

In the rat, the evidence shows that succinylsulphathiazole is excreted against a concentration gradient from plasma to bile. The excretory process can be saturated by high doses of succinylsulphathiazole whose maximum excretion rate by the liver is about $230 \mu \mathrm{moles} / \mathrm{kg}$. body wt. $/ 3 \mathrm{hr}$. Further, the simultaneous administration of sodium taurocholate or phenolphthalein glucuronide, which are also excreted in the bile, depresses the secretion of the drug, probably by competition for the same transfer process. The maximum rate of biliary excretion of phenolphthalein glucuronide in the rat is similar to that of succinylsulphathiazole, i.e. about $230 \mu \mathrm{moles} / \mathrm{kg}$. body wt. $/ 3 \mathrm{hr}$. and, when these two substances are administered together at dose levels capable of saturating the transfer mechanism, the sum of the amounts of the two compounds excreted in the bile is still about $230 \mu \mathrm{moles} / \mathrm{kg}$. body wt./3hr.

In the rabbit, however, succinylsulphathiazole apparently does not enter the liver readily, and this suggests a difference in the membrane character in the two species. Further, the rabbit appears to be deficient in the mechanism, which occurs in the rat, responsible for the concentrative transfer of the sulphonamide from the liver to the bile. These two factors, entry into the liver and transfer to the bile, are probably at least partly responsible for the difference in the biliary excretion of the sulphonamide in the two species.

M.M.A.-E.-M. participated in this work during the tenure of a Scholarship from the U.A.R. Education Bureau. We are grateful to Professor R. T. Williams for his interest in this work.

\section{REFERENCES}

Abou-El-Makarem, M. M., Millburn, P., Smith, R. L. \& Williams, R. T. (1967a). Biochem.J.103, 25 P.

Abou-El-Makarem, M. M., Millburn, P., Smith, R. L. \& Williams, R. T. (1967b). Biochem. J. 105, 1269.

Abou-El-Makarem, M. M., Millburn, P., Smith, R. L. \& Williams, R. T. (1967c). Biochem. J. 105, 1289.

Millburn, P., Smith, R. L. \& Williams, R. T. (1967a). Biochem. J. 105, 1275.

Millburn, P., Smith, R. L. \& Williams, R. T. (1967b). Biochem. J. 105, 1283. 